\title{
Innovative Approach for Effecting Improved Mordant Dyeing of Cotton Textiles
}

\author{
A.Hebeish, Kh. Elnagar* and M.F. Shaaban" \\ Textile Research Division, National Research Centre, Dokki, \\ Scopus Affiliation ID 60014618 and *Textile Lab., National \\ Institute for Standards, Haram-Giza, Egypt.
}

\begin{abstract}
B LEACHED cotton fabrics were submitted to successive treatments , Viz., $\mathrm{UV} / \mathrm{O}_{3}$ irradiation and chitosan treatments. Thus obtained irradiated-chitosan treated fabrics form the base of innovations whereby high improvement in mordant dyeing as well as in antibacterial activity of the cotton fabrics could be achieved. Mordant dyeing was performed as per three methods: 1) Premordanting where the irradiated-chitosan treated fabric was mordanted prior to dyeing. 2) Meta-mordanting involved conducting dyeing to a mid-way point at which the mordant was added and dyeing continued till completion ; and 3)Post-mordanting refers to complete dyeing followed by mordanting of the dyed fabric in a separate step. Two natural dyes, namely, curcumin and hibiscus were used. Mordants used were zinc acetate and cadmium acetate. As envisioned the $\mathrm{UV} / \mathrm{O}_{3}$ irradiation of cotton fabric causes profound changes in the physical and chemical structure of cotton. These changes are ameliorated by further treatment of the irradiated fabric by chitosan. $\mathrm{UV} / \mathrm{O}_{3}$ irradiation in combination with chitosan treatment plays a significant role in the mode of interactions of cotton with the mordant as well as with the dye itself during mordant dyeing.
\end{abstract}

Keywords: Chitosan, Mordant, Curcumin, Hibiscus, Natural dyes, Fastness properties, Silver nanoparticles and Antibacterial activity.

During the pre-historical eras, natural dyes had been used in coloring clothes, rugs and carpets. Ancient Egyptians used natural dyestuffs extracted from many renewable sources, such as plants, insects, minerals and fungi ${ }^{(1)}$. By the end of the $19^{\text {th }}$ century, synthetic dyestuffs replaced the natural dyes. However, new researches assured that dyeing with synthetic dyes has a negative effect on the environment as they are considered one of the main pollutants ${ }^{(2)}$. This led to reusing the natural dyes by virtue of their excellent eco-friendly properties such as low toxicity, bio-degradability and low allergic and carcinogen effect ${ }^{(3,4)}$. Furthermore, natural dyes possess distinctive washing and sun light fade-resistant properties ${ }^{(5)}$, as well as textile materials demand and value added along with better look which are the desire of today customers ${ }^{(5-7)}$. Recent researches deal with different types of natural dyes which can be originated from animals, e.g. cochineal insect (red), cow urine (Indian yellow) and octopus/cuttlefish (sepia

\#E-mail address: drmohamed727@gmail.com 
brown), or from plants, e.g. Gamboges tree resin (dark mustard yellow) and Hibiscus trees ${ }^{(8)}$.

Different irradiation techniques were applied with view to enhance the fastness properties of cotton dyed with natural dyes. Of these techniques mention is made of the following: corona discharge treatment ${ }^{(9)}$, plasma functionalization ${ }^{(10,11)}$, laser induced surface modification ${ }^{(12)}$, gamma irradiation (13), UV irradiation (14), ultrasound vibration ${ }^{(15,16)}$, electron beam irradiation ${ }^{(16)}$, microwave curing ${ }^{(17)}$, supercritical carbon dioxide technique ${ }^{(16)}$, vapor deposition ${ }^{(16)}$ and ozone-gas treatment ${ }^{(18)}$.

Previous reports ${ }^{(15,19)}$ postulated the following scheme for the effect of $\mathrm{UV} / \mathrm{O}_{3}$ radiation on polyamide materials.

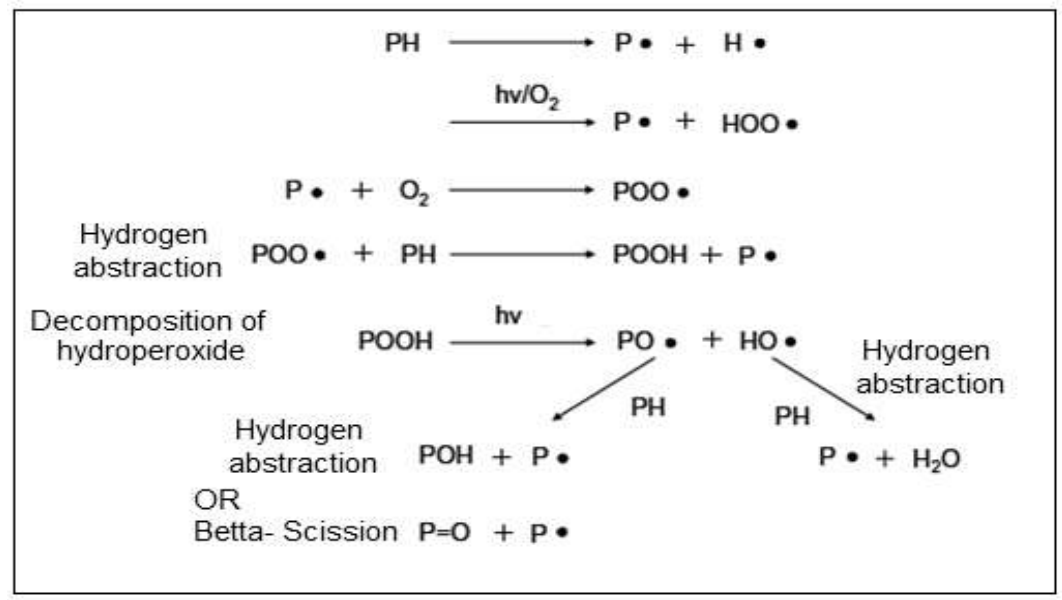

Scheme 1. The effect of $\mathrm{UV} / \mathrm{O}_{3}$ radiation on polymeric materials.

In a recent study ${ }^{(20)}$, samples of cotton fabric were subjected to $\mathrm{UV} / \mathrm{O}_{3}$ irradiation and the obtained irradiated samples were treated with chitosan. Changes in surface characteristics as well as in micro-morphological features of cotton cellulose were assessed using scanning electron microscopy (SEM). In combination with this, the impact of such changes on the magnitude of interaction of chitosan with the cellulose molecules of the fabric was realized through nitrogen analysis. Hence, a comparison was made among SEM micrographs of untreated cotton, chitosan treated cotton and pre-irradiated cotton followed by chitosan treatment. Meanwhile, fabrics containing chitosan were analyzed for nitrogen.

Results of the above study conclude that fabrics treated with chitosan without $\mathrm{UV} / \mathrm{O}_{3}$ irradiation exhibit relatively higher enlargement; the lowest enlargement is, indeed, observed after $\mathrm{UV} / \mathrm{O}_{3}$-irradiation. Fabric coated with chitosan acquires a veil-forming like that formed on $\mathrm{UV} / \mathrm{O}_{3}$ irradiated -chitosan treated fabric. The interaction of the irradiated fabrics with chitosan seems to be affected

Egypt. J. Chem. 58, No. 4 (2015) 
substantially by morphological and microstructure changes and their onset on the nature and surface area of cotton cellulose in addition to creation of reducing aldehydic and acidic carboxylic groups under the oxidative action of $\mathrm{UV} / \mathrm{O}_{3}$ radiation. Nevertheless, chitosan concentrations play essential role in determining the magnitude of chitosan-irradiated cotton interaction ${ }^{(20)}$.

The present work addresses a novel approach for enhancement of mordanting dyeing using natural dyes, The aforementioned $\mathrm{UV} / \mathrm{O}_{3}$ irradiated-chitosan treated fabrics form the base of such innovative approach whereby excellent mordant dyeing can be achieved. Pre-, meta- and post-mordanting dyeing are applied to dye cotton fabrics using two natural dyes, namely, Curcumin and hibiscus dyes at different concentrations. The effect of these variables as well as nature and concentration of the mordant, exemplified by zinc acetate and cadmium acetate on color strength and overall fastness properties are studied.

\section{Materials}

\section{Experimental}

Mill-bleached cotton fabric was further purified through scouring by treatment in a solution containing sodium carbonate $(5 \mathrm{~g} / \mathrm{l})$ along $(2 \mathrm{~g} / \mathrm{l})$ with Hostapal C.V ${ }^{\circledR}$ (non-ionic detergent -Clarient). Curcumin and hibiscus plants were purchased from the local market. Acetic acid, hydrochloric acid, ,citric acid (C.A), sodium carbonate, caustic soda, zinc acetate cadmium acetate and sodium hypophosphite (SHP), were all of laboratory grade chemicals.

\section{Methods}

Scouring of cotton

The grey fabric was scoured using aqueous solution containing Hostapal C.V® $(2 \mathrm{~g} / \mathrm{l})$ and sodium carbonate $(5 \mathrm{~g} / \mathrm{l})$ at $90^{\circ} \mathrm{C}$ for $1 \mathrm{hr}$, then rinsed with hot and cold water and finally dried at $100^{\circ} \mathrm{C}$ for $2 \mathrm{~min}$.

\section{$\mathrm{UV} / \mathrm{O}_{3}$ irradiation}

The samples under test in the form of stripes were firstly exposed to UV source in a medium of ozone for $90 \mathrm{~min}$. A high intensity, low pressure mercury lamp without outer envelope-LRF-02971, 200 watt, 220 volts, ,made in Poland, was placed in a cubic box with side length $60 \mathrm{~cm}$, and the samples were put around the source at a distance of $20 \mathrm{~cm}$. When molecular oxygen is subjected to the $184.9 \mathrm{~nm}$ irradiation and ozone is irradiated at $253.7 \mathrm{~nm}$, the radiation is adsorbed by most hydrocarbons and also by ozone ${ }^{(21)}$. The products of this excitation react with atomic oxygen to form simpler, volatile molecules, which are desorbed from the surface of the cotton fabric. Therefore, when both wavelengths are present atomic oxygen is continuously generated and ozone is continually formed and then destroyed ${ }^{(21,22)}$.

\section{Chitosan treatment}

The purpose of this process is to treat the $\mathrm{UV} / \mathrm{O}_{3}$ irradiated samples with chitosan prior to the mordanting and dyeing processes. The irradiated samples 
were treated with different concentrations of chitosan (0-4\%) of freshly prepared chitosan solution in $1 \%$ acetic acid . Chitosan solutions contained $8 \mathrm{~g} / \mathrm{l}$ citric acid (CA) as a crosslinking agent and $4 \mathrm{~g} / \mathrm{l}$ sodium hypophosphite (SHP) as a catalyst. Samples of the cotton fabrics were padded separately with the chitosan solutions with a wet pick-up $100 \%$ and dried at $85^{\circ} \mathrm{C}$ for $5 \mathrm{~min}$, followed by thermofixation at $170^{\circ} \mathrm{C}$ for $2 \mathrm{~min}$. The treated samples were washed several times with cold water, and then dried at ambient condition (temperature of $25 \pm 2{ }^{\circ} \mathrm{C}$ and relative humidity $65 \% \pm 5$ ) and their nitrogen content was measured ${ }^{(23)}$.

\section{Natural dye extraction process}

A certain quantity of the plant powder $(0.5 \mathrm{~g})$ was immersed in a $250 \mathrm{ml}$ stopperd conical flask using $100 \mathrm{ml}$ of distilled water, then raising the temperature to $100^{\circ}$ for one hour and then cooling the extract to room temperature and filtering it using Wattman 40 filter paper to get the dyestuff extract solution.

\section{Mordanting}

The fabric samples were mordanted, using one of the mordants under study, i.e. zinc acetate or cadmium acetate, as per the three mordanting methods for dyeing ; pre-mordanting, i.e. prior to dyeing; meta-mordanting, i.e. in the middle of dyeing and; post- mordanting, i.e. after dyeing. In each case the fabric samples were padded twice in the mordant solution, i.e. in the aqueous solution of the metallic salt $(200 \mathrm{mg} / \mathrm{l})$ to a wet pick up of $100 \%$. The treated fabric samples were then rinsed thoroughly with hot water followed by cold water and dried at $100^{\circ} \mathrm{C}$ for $3 \mathrm{~min}$.

\section{Dyeing process}

1- In the process of pre-mordanting dyeing, fabric samples loaded with the deposited metal oxides were immersed in a dye bath containing the natural dye $(5 \%$ o.w.f)and nonionic wetting agent $(0.5 \mathrm{~g} / \mathrm{l})$. Dyeing was conducted using dye: liquor ratio $(1: 20)$, at $\mathrm{pH}$ adjusted to 8 using $\mathrm{NaOH}$. The dye bath temperature was gradually raised (about $2^{\circ} \mathrm{C} / \mathrm{min}$ ) up to $60^{\circ} \mathrm{C}$ and was kept at this temperature for $60 \mathrm{~min}$. The dye bath temperature was then allowed to cool to about $40^{\circ} \mathrm{C}$. At this end, the dyed fabric samples were squeezed, rinsed thoroughly with hot and cold water and air dried.

2- In meta-mordanting process; after being subjected to $30 \mathrm{~min}$ - dyeing at $60^{\circ} \mathrm{C}$ the fabric was removed from the dye bath dried at $100^{\circ} \mathrm{C}$ to be padded twice in aqueous solution of the metallic salt $(200 \mathrm{mg} / \mathrm{l})$ to a wet pick up of $100 \%$ and then immersed again into the dyeing bath and the dyeing process continued as above.

3- In the post-mordanting dyeing process, dyeing was carried out as previously described, dried at $100^{\circ} \mathrm{C}$ followed by padding the dyed fabric twice in aqueous solution of the metallic salt $(200 \mathrm{mg} / \mathrm{L})$ to a wet pick up $100 \%$, then dried at $100^{\circ} \mathrm{C}$ for $2 \mathrm{~min}$.

Egypt. J. Chem. 58, No. 4 (2015) 
Testing and analysis

Color strength $(K / S)$

Color strength of the dyed fabric samples, in terms of the K/S values, was obtained by using the Kubelka Munk equation ${ }^{(24)}$ :

$$
K / S=\frac{(1-R)^{2}}{2 R}
$$

where $\mathrm{K}$ is the light absorption coefficient, $\mathrm{S}$ is the scattering coefficient and $\mathrm{R}$ is the reflectance of the dyed samples at the wavelength the maximum absorption. The color strength of the treated samples was evaluated by Hunter Lab Ultra scan Pro E313, D65/10 -USA at $\lambda$ max. 360nm.

\section{Fastness properties}

The dyed samples were submitted to washing and rubbing color fastness according to the AATCC as per the conditions specified in the test of AATCC No. 68 methods no. 8, 15 and 16A (1989).

\section{Result and Discussion}

\section{Tentative mechanism}

We have very recently disclosed ${ }^{(20)}$ that exposure of cotton cellulose to $\mathrm{UV} / \mathrm{O}_{3}$ radiation causes substantial cleavages in the physical and chemical structure of the cellulose. The latter undergoes alterations in morphology, microstructure and surface characteristics in addition to creation of aldehydic and carboxylic groups. Based on previous reports ${ }^{(15,19)}$ dealing with polyamide, the following free radicals mechanism for oxidation of cotton cellulose ( Cell- $\mathrm{OH}$ ) under the influence of $\mathrm{UV} / \mathrm{O}_{3}$ irradiation may be plausible.

Cellulose and hydrogen free radicals are formed through hydrogen abstraction as suggested by Equation 1 :

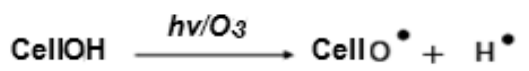

Addition of oxygen to cellulose and hydrogen free radicals leads to their peroxide radicals (Equations 2 and 3) which are converted to the hydroperoxides (Equations 4 and 5)

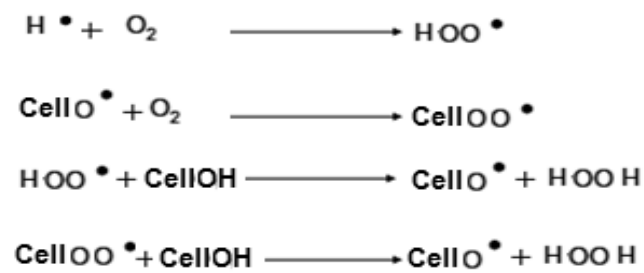


The so formed hydrogen peroxide decomposes to yield hydroxyl free radical (Equation 6);

$$
\mathrm{HOOH} \stackrel{h \mathrm{r}}{\longrightarrow} \mathrm{HO}^{\bullet}+\mathrm{HO}^{\bullet}
$$

Decomposition of the hydroperoxide is shown by the reactions suggested by Equation 7.

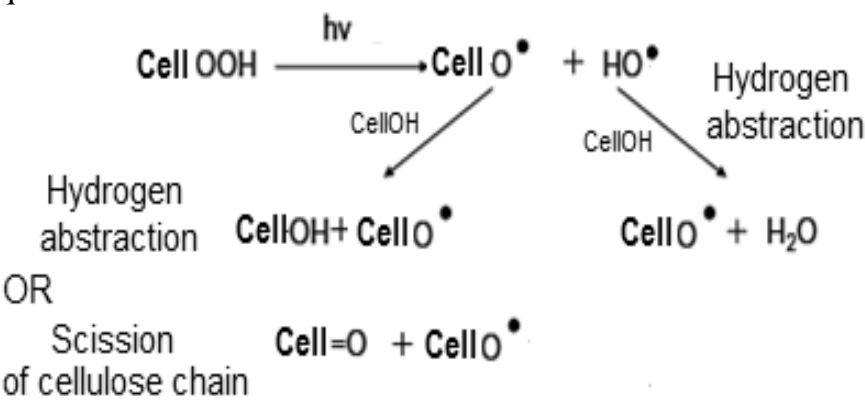

The idea of the current work is to make use of the structural change in cotton cellulose brought about by the effect of hv/ $\mathrm{O}_{3}$ irradiation and chitosan treatmentwhen carried out separately and in succession for development of improved mordant dyeings. The study comprises the impact of nature and concentration of the dye, nature and concentration of the mordant, and method of mordanting on color strength and fastness to washing and to rubbing. Irradiated-chitosan treated cotton fabric vis-a-vis (untreated control) sample.

The substrate of choice

During the performance of this work, we have been dealing with several substrates, namely, untreated cotton fabric, cotton fabric treated with chitosan, cotton fabric treated with $\mathrm{UV} / \mathrm{O}_{3}$ radiation and $\mathrm{UV} / \mathrm{O}_{3}$ irradiated fabric treated with chitosan. Preliminary investigation confirmed the superisity of $\mathrm{UV} / \mathrm{O}_{3}$ irradiated-chitosan treated cotton fabric with respect to the latter behavior towards mordanting dyeing. This peculiar substrate exhibits higher color strength and overall fastness properties when submitted to mordanting dyeing using natural dyes.

In previous reports ${ }^{(21)}$, the response of cotton fabric to $\mathrm{UV} / \mathrm{O}_{3}$ irradiation was evidenced by reducing elasticity and the average molecular chain of the treated fabric most probably due to photo-oxidation. These irradiated fabrics are liable to react with chitosan either through coating and/or cross linking under the effect of free radicals resulting from the photo-chemical action of $\mathrm{UV} / \mathrm{O}_{3}$ on the cotton cellulose of the fabric.

Nature of the dye

Two different natural dyes, namely, hibiscus and curcumin tinchotoria were Egypt. J. Chem. 58, No. 4 (2015) 
used. Hibiscus is a flowering plant which is part of the mallow family. They are found in tropical areas and can be grown as a potted plant on patios during the summer ${ }^{(25)}$. On the other hand, curcumin is a yellow-orange compound derived from the root of Curcuma longa (Zingiberaceae family), that has been used as a medicine, spice and coloring agent ${ }^{(26)}$. Chemical structures of the two dyes are represented by formulae $\mathrm{A}$, as drawn below.
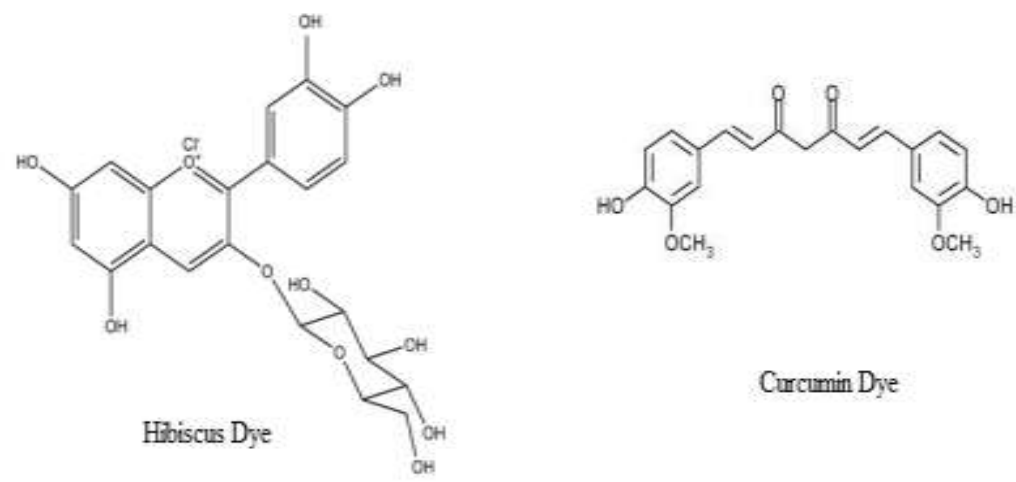

A- Chemical formulae of the two natural dyes used.

Dependence of the color strength, expressed as k/s, on nature of the dye may be realized from Fig. 1-6. As evident, cotton fabric samples dyed with curcumin dye exhibit much higher $\mathrm{k} / \mathrm{s}$ values than those dyed with hibiscus dye. This is observed regardless of the mordent and melled of mordenting used. The reason for this refers to great stability of the curcumin than the hibiscus dye. The structure of curcumin dye is more resonance stable than hibiscus and its ketoEnol form (formula B) when attached to the cellulose carrying the mordant will be more stable than in case of hibiscus ,thereby leading to more color strength.

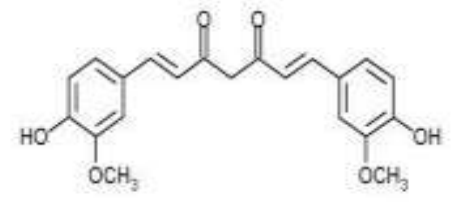

a

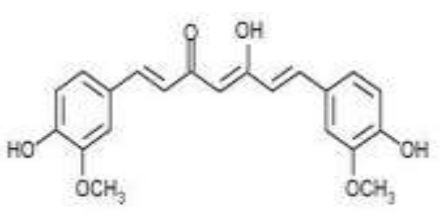

b

B- Chemical structure formula of curcumin a-Keto form b-Enol form .

Nature of concentration of the mordant

In common practice the principle of using mordant during dyeing of cotton fabrics with natural dyes is a manifestation of the wear attachment of the dye to cotton cellulose even after treating the latter with chitosan. The positive effect of the mordant on color strength of fabric samples dyed as per-mordanting dyeing using different concentrations of two mordants, namely zinc acetate and cadmium acetate is shown in Fig. 1-6. Results of these figures show that increasing the mordant concentration causes increment in the color strength until certain concentration $(200 \mathrm{mg} / \mathrm{l})$ is attained. Thereafter, the color strength 
decreases by further increasing the mordant concentration irrespective of the method of mordanting used. At mordant concentration of $200 \mathrm{mg} / \mathrm{l}$, it is logical that cellulose lattice is saturated with the mordant and the adsorption decreases thereafter due to saturation ${ }^{(27)}$.

A close examination of the results of Fig. 1-6 as well these of Table 1 would reveal that there is no cut-clear and significant difference among the two mordants under investigation. That is nature of the mordant does not play a curious role in deciding the magnitude of color strength of mordant by dyed fabric within the range studied.

\section{Method of mordanting}

Table 1 (of Fig. 1-6) shows variations of color strength (k/s) with the methods of mordenting which include pre-, meta and post mordanting. Obviously, the k/s displays values which advocate pre mordenting dyeing as the best among the three methods examined. Apart of affecting relatively higher concentration and distribution of the mordant onto the fabric, the pre-mordanting method versus the meta- and post-mordanting methods avail themselves to the following explanations:

i) In pre-mordanting; the metal ions in the mordant solution on the fabric are coordinated to the cellulose -chitosan molecule where no other dye molecules exist therein to compete with this coordination which involves interaction with the cellulose lattice. Following this, the natural dye molecules will only interact with the mordant molecules producing more color depth since the dye-mordant bond is stronger than dye-cellulose.

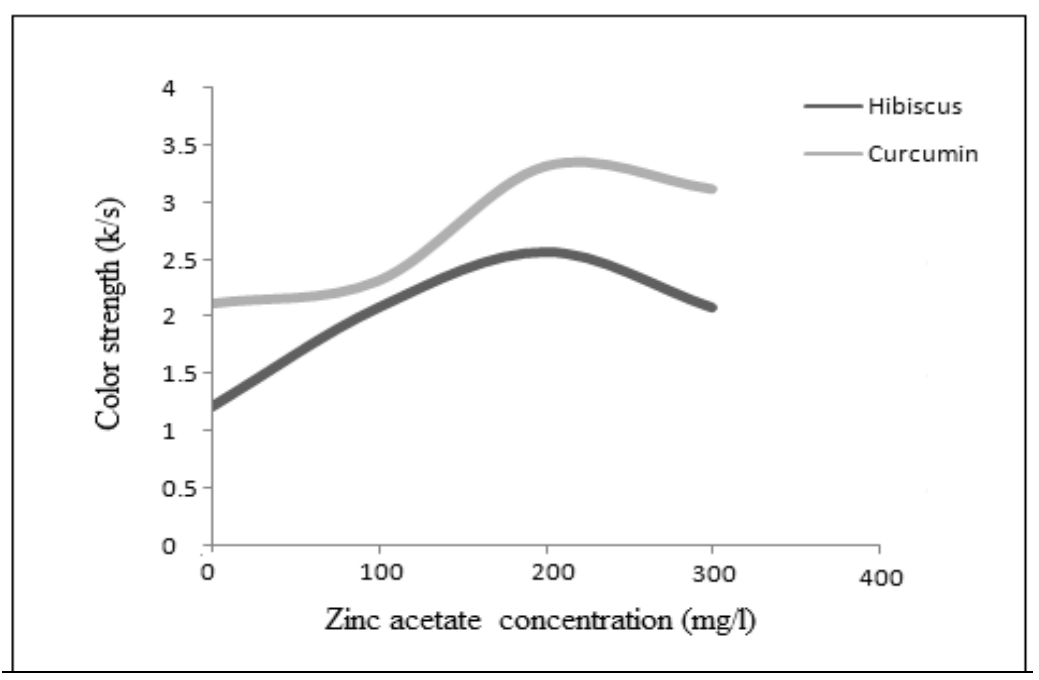

Fig. 1. Effect of zinc acetate concentration on color strength (Pre-mordanting).

Egypt. J. Chem. 58, No. 4 (2015) 


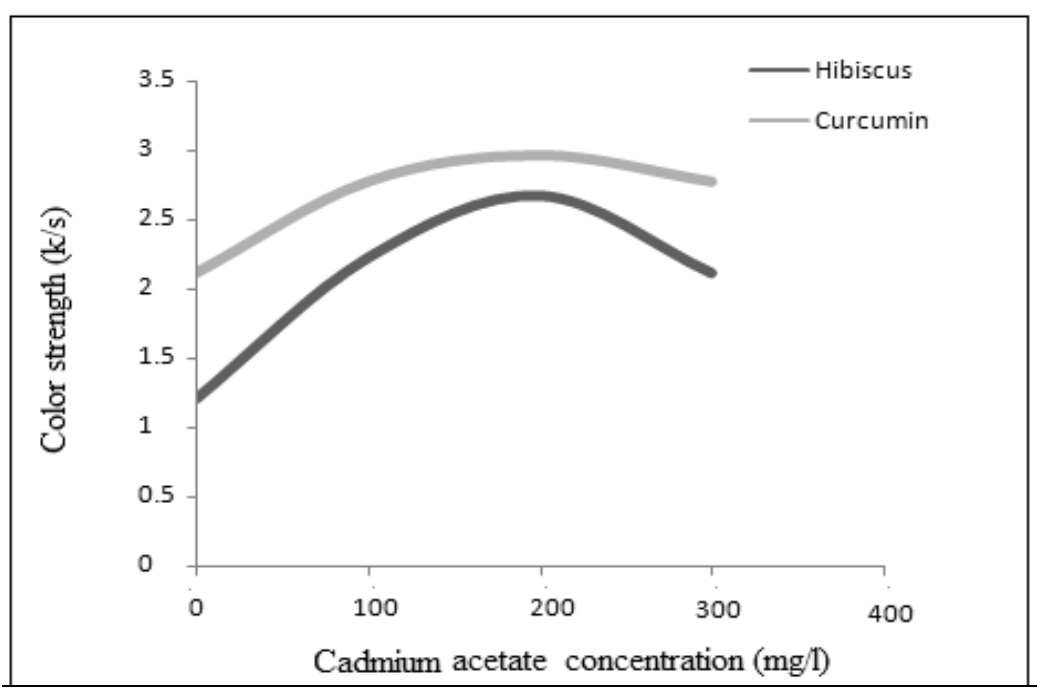

Fig. 2. Effect of cadmium acetate concentration on color strength (Pre-mordanting).

ii) In meta-mordenting; there is almost equal chance for both of the dye molecules and mordant molecules to interact with the cellulose-chitosan molecules. So, there is an intermediate probability for both interactions leading to lower dye uptake and color strength.

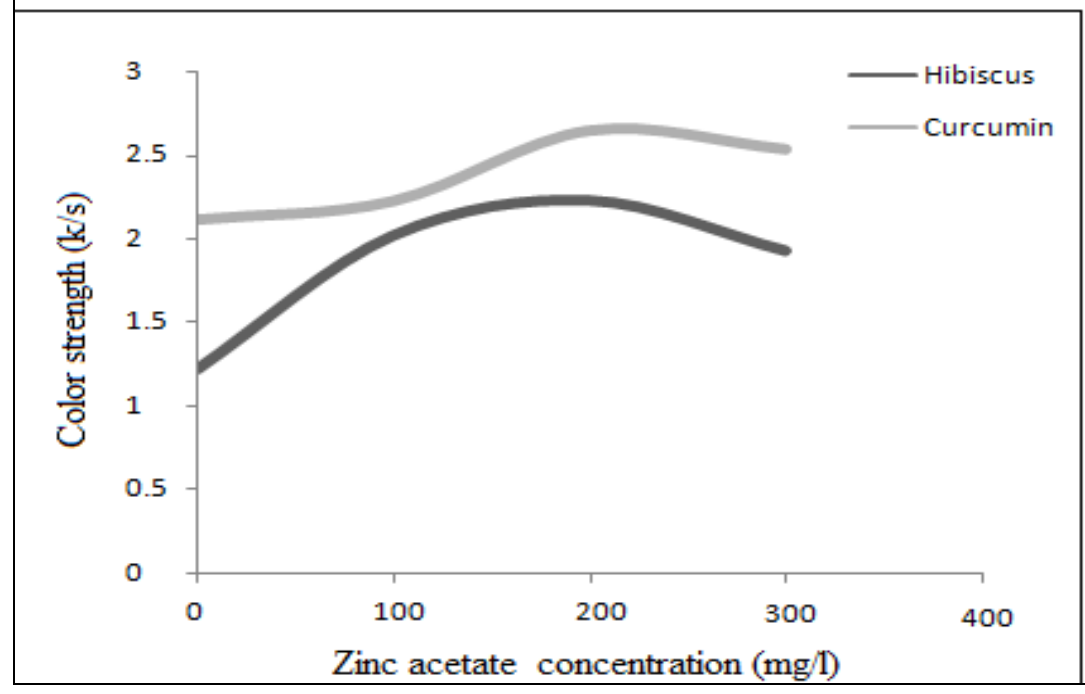

Fig. 3. Effect of zinc acetate concentration on color strength (Meta-mordanting). 


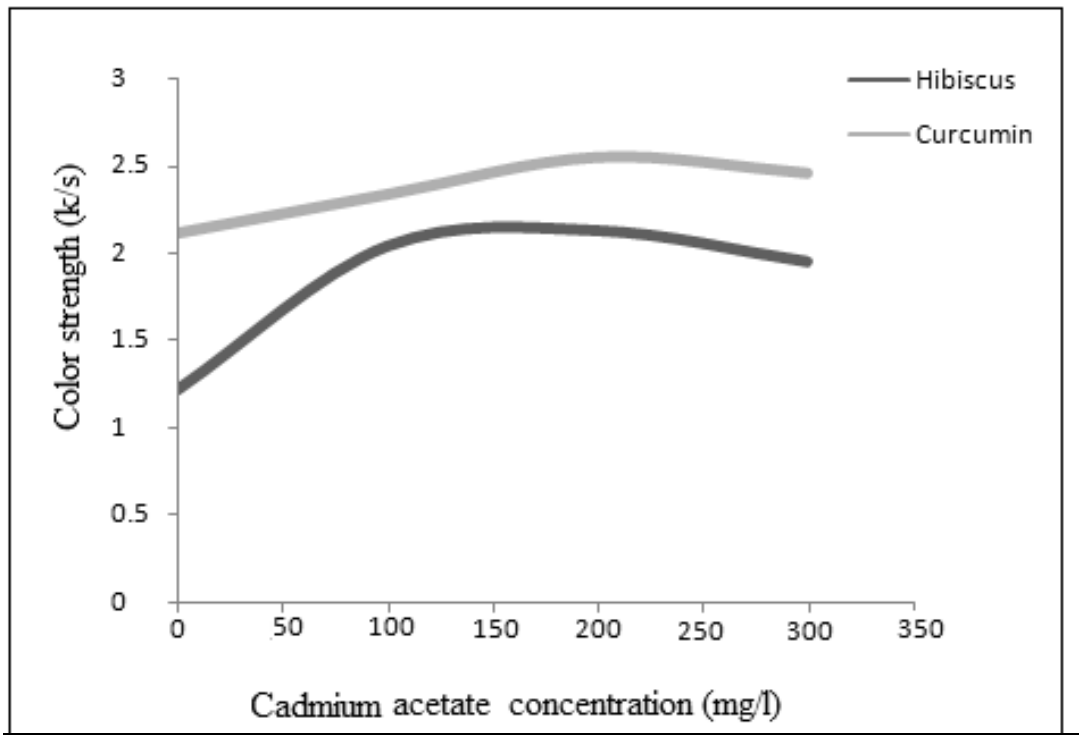

Fig. 4. Effect of cadmium acetate concentration on color strength (Meta-mordanting).

iii) In post mordenting, the mordant molecules have much less chance to interact with the cellulose-chitosan molecules which are already involved in interactions with the dye. Interaction of the dye molecules with the fabric will certainly decrease the opportunity of interaction of the mordant molecules with cellulose. This results in dye up-take and color strength which are lower than metamordanting.

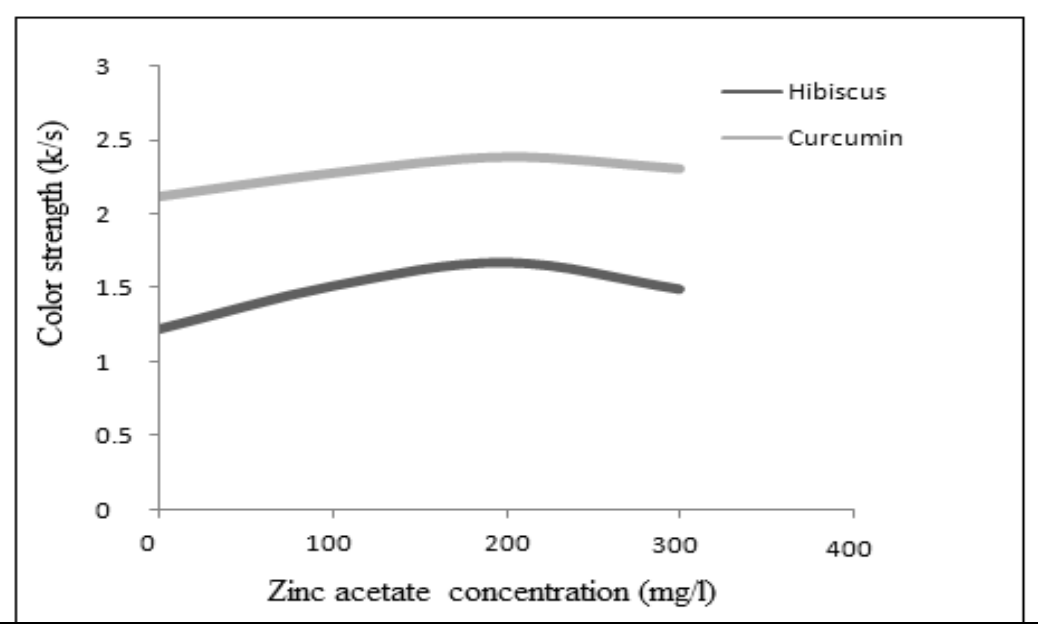

Fig. 5. Effect of zinc acetate concentration on color strength (Post-mordanting).

Egypt. J. Chem. 58, No. 4 (2015) 


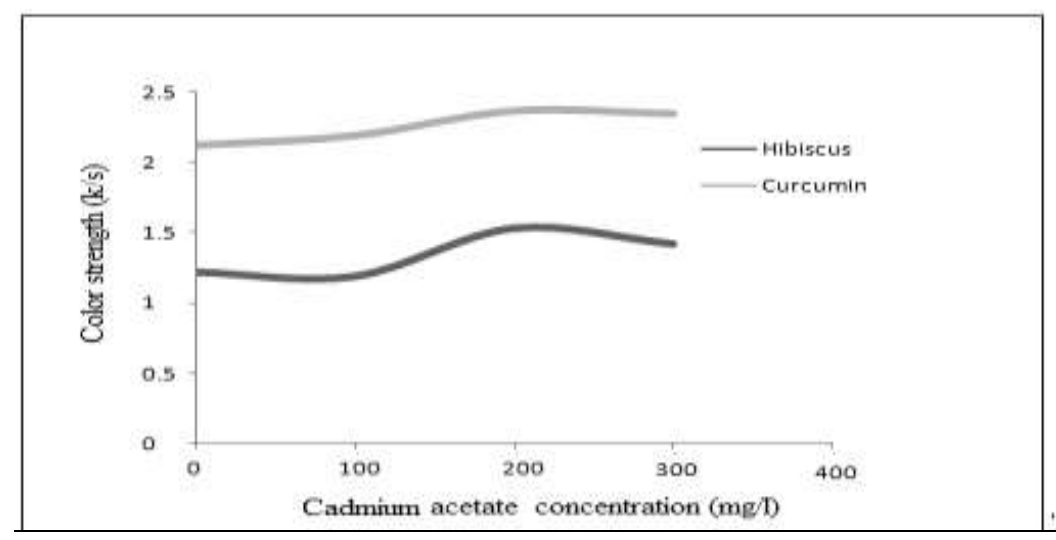

Fig. 6. Effect of cadmium acetate concentration on color strength (Post-mordanting).

Examination of Table 1 signify that the color strength $(\mathrm{k} / \mathrm{s})$ obtained with the these aforementioned three methods of mordant dyeing follows the order:

$$
\text { pre-mordanting > meta-mordanting }>\text { post- mordanting }
$$

TABLE 1. The color strength $(\mathrm{K} / \mathrm{S})$ of natural dyes on $\mathrm{UV} / \mathrm{O}_{3}$ irradiated-chitosan treated cotton fabrics when mordant dyeing was effected using different methods for dyeing and different mordant concentrations as well as two different natural dyes.

\begin{tabular}{|c|c|c|c|c|c|c|}
\hline Technique & Pre-mordanting & \multicolumn{2}{|c|}{ Meta- mordanting } & Post-mordanting \\
\cline { 1 - 7 } Sample Dye & Hibiscus & Curcumin & Hibiscus & Hibiscus & Hibiscus & Hibiscus \\
\hline $100 \mathrm{ppm}(\mathrm{Zn})$ & 2.08 & 2.32 & 2.02 & 2.23 & 1.51 & 2.28 \\
\hline $200 \mathrm{ppm}(\mathrm{Zn})$ & 2.56 & 3.32 & 2.23 & 2.65 & 1.67 & 2.39 \\
\hline $300 \mathrm{ppm}(\mathrm{Zn})$ & 2.08 & 3.12 & 1.93 & 2.54 & 1.49 & 2.31 \\
\hline $100 \mathrm{ppm}(\mathrm{Cd})$ & 2.24 & 2.78 & 2.05 & 2.34 & 1.19 & 2.19 \\
\hline $200 \mathrm{ppm}(\mathrm{Cd})$ & 2.69 & 2.97 & 2.14 & 2.55 & 1.53 & 2.37 \\
\hline $300 \mathrm{ppm}(\mathrm{Cd})$ & 2.13 & 2.78 & 1.96 & 2.46 & 1.42 & 2.35 \\
\hline Blank & 1.22 & 2.12 & \multicolumn{6}{|c|}{ K/S at 360 nm without mordants } \\
\hline
\end{tabular}

This is the case irrespective of the natural dye used. however, for a given method and mordant concentration the curcumin natural dye brings about higher color strength than does the hibiscus dye for reasons cited above. Meanwhile the order found upon comparing the three mordanting dyeing is assumed to have direct relation with the mode by which the mordant is attached to the cellulose.

\section{Color fastness properties}

Color fastness to washing

Table 2 illustrates the effect of mordanting as per the three methods in question on the fasteness properties to washing. Fastness to washing was monitored in terms of color change and staining compared to the blank. As 
evident mordanted samples display higher washing fasteness than does the unmordanted sample. The highest fasteness degree increases from (2/3 and 3$)$ for color change in case of hibiscus and curcumin respectively to ( 3 and $3 / 4)$ and from (4/5 and 3 ) for staining to (5 and 3/4). In all cases mordant concentration $(200 \mathrm{mg} / \mathrm{l})$ was used. This refers to enhancement in fasteness properties due to mordanting. It is well to note that.

Pre-mordanting and meta-mordanting gave better results than postmordanting ; a point which could be associated with the stability of dye and the dye fixation that were lowered upon exercising post-mordanting than pre and meta mordanting.

\section{Color fastness to rubbing}

A close examination of the results shown in Table 2 would reveal that rubbing fasteness of the dyeings is improved upon using mordants, in full conformation with washing fasteness. Also, observed is the better enhancement in fasteness to rubbing upon using vis-a-vis post-mordanting.

TABLE 2. Color fastness properties of hibiscus and curcumin natural dyes on $\mathrm{UV} / \mathrm{O}_{3}$ irradiated -chitosan treated cotton fabrics when the latter was mordanting dyeing as per the pre-mordanting, meta-mordanting and post -mordanting dyeing.

\begin{tabular}{|c|c|c|c|c|c|c|c|c|}
\hline \multirow{3}{*}{ Dample Used } & \multicolumn{4}{|c|}{ Hibiscus } & \multicolumn{4}{|c|}{ Curcumin } \\
\hline & \multirow{2}{*}{$\begin{array}{c}\text { Color } \\
\text { change }\end{array}$} & \multirow[b]{2}{*}{ Staining } & \multicolumn{2}{|c|}{ Rubbing } & \multirow{2}{*}{$\begin{array}{c}\text { Color } \\
\text { change }\end{array}$} & \multirow[b]{2}{*}{ Staining } & \multicolumn{2}{|c|}{ Rubbing } \\
\hline & & & wet & dry & & & wet & dry \\
\hline Blank & $2 / 3$ & $4 / 5$ & 4 & $4 / 5$ & 3 & 3 & $3 / 4$ & 4 \\
\hline \multicolumn{9}{|c|}{ Post-Mordanting } \\
\hline $100 \mathrm{ppm}(\mathrm{Zn})$ & 3 & 5 & $4 / 5$ & 5 & $3 / 4$ & $3 / 4$ & 4 & $4 / 5$ \\
\hline 200ppm(Zn) & 3 & 5 & 5 & 5 & $3 / 4$ & $3 / 4$ & 4 & $4 / 5$ \\
\hline 300ppm $(\mathrm{Zn})$ & 3 & 5 & 5 & 5 & $3 / 4$ & $3 / 4$ & 4 & $4 / 5$ \\
\hline $100 \mathrm{ppm}(\mathrm{Cd})$ & 3 & 5 & $4 / 5$ & 5 & $3 / 4$ & $3 / 4$ & 4 & $4 / 5$ \\
\hline $200 \mathrm{ppm}(\mathrm{Cd})$ & 3 & 5 & 5 & 5 & $3 / 4$ & $3 / 4$ & 4 & $4 / 5$ \\
\hline 300ppm $(\mathrm{Cd})$ & 3 & 5 & 5 & 5 & $3 / 4$ & $3 / 4$ & 4 & $4 / 5$ \\
\hline \multicolumn{9}{|c|}{ Meta-Mordanting } \\
\hline 100ppm(Zn) & 3 & 5 & $4 / 5$ & 5 & $3 / 4$ & $3 / 4$ & 4 & $4 / 5$ \\
\hline 200ppm(Zn) & 3 & 5 & 5 & 5 & $3 / 4$ & $3 / 4$ & 4 & $4 / 5$ \\
\hline 300ppm(Zn) & 3 & 5 & 5 & 5 & $3 / 4$ & $3 / 4$ & 4 & $4 / 5$ \\
\hline $100 \mathrm{ppm}(\mathrm{Cd})$ & 3 & 5 & $4 / 5$ & 5 & $3 / 4$ & $3 / 4$ & 4 & $4 / 5$ \\
\hline 200ppm(Cd) & 3 & 5 & 5 & 5 & $3 / 4$ & $3 / 4$ & 4 & $4 / 5$ \\
\hline 300ppm $(\mathrm{Cd})$ & 3 & 5 & 5 & 5 & $3 / 4$ & $3 / 4$ & 4 & $4 / 5$ \\
\hline \multicolumn{9}{|c|}{ Pre-Mordanting } \\
\hline $100 \mathrm{ppm}(\mathrm{Zn})$ & $2 / 3$ & 5 & $4 / 5$ & 5 & 3 & 3 & 4 & $4 / 5$ \\
\hline 200ppm(Zn) & $2 / 3$ & 5 & 5 & 5 & 3 & 3 & 4 & $4 / 5$ \\
\hline 300ppm(Zn) & $2 / 3$ & 5 & 5 & 5 & 3 & 3 & 4 & $4 / 5$ \\
\hline $100 \mathrm{ppm}(\mathrm{Cd})$ & $2 / 3$ & 5 & $4 / 5$ & 5 & 3 & 3 & 4 & $4 / 5$ \\
\hline 200ppm $(\mathrm{Cd})$ & $2 / 3$ & 5 & 5 & 5 & 3 & 3 & 4 & $4 / 5$ \\
\hline $300 \mathrm{ppm}(\mathrm{Cd})$ & $2 / 3$ & 5 & 5 & 5 & 3 & 3 & 4 & $4 / 5$ \\
\hline
\end{tabular}

Egypt. J. Chem. 58, No. 4 (2015) 


\section{Conclusion}

Innovative approach was established for improving dye fixation, color strength, fastness to washing and fastness to rubbing of mordant dyeings. Pertaining to fabrics dyed independently with two natural dyes. the latter encompassed curcumin dye and hibiscus dye which were applied to cotton fabrics as per the pre-, meta- and post-mordanting dyeing. Cotton fabric submitted to $\mathrm{UV} / \mathrm{O}_{3}$ radiation followed by treatment with chitosan in a subsequent step forms the substrate of choice. Dyeing of this substrate according to the pre-mordanting dyeing method in presence of zinc acetate or cadmium acetate forms the core of current innovation. That is, physico-chemical modification of cotton fabric by subjecting it to $\mathrm{UV} / \mathrm{O}_{3}$ radiation followed by chitosan treatment induces micro structural changes in the cotton cellulose of the fabric. Cotton fabric so treated acquires greater interactions with the treatment as well as with the natural dye and, in turn, with the fabric to yield ultimately mordant dyeings with higher performance.

\section{References}

1. Chakraborty, J. N., "Fundamentals and Practices in Colouration of Textiles", $2^{\text {nd }}$ ed. Woodhead Publishing India, pp. 233-261(2014).

2. Rehman, F., Adeel, S., Qaiser Summia, Bhatti, A. Ijaz, Shahid, M. and Zuber, M., Dyeing behaviour of gamma irradiated cotton fabric using Lawson dye extracted from henna leaves (Lawsonia inermis). Radiation Physics and Chemistry,81(11), $1752-1756$ (2012).

3. Ibrahim, N.A., Elgamal, A.R., Gouda, M. and Mahrous, F., A new approach for natural dyeing and functional finishing of cotton cellulose. Carbohydrate Polymers, 82,1205-1211(2010).

4. Bechtold, T. and Mussak, R., "Handbook of Natural Colorants", $2^{\text {nd }}$ ed. Sous ltd.,UK, pp.153-156 (2009)

5. Daniela, Cristea and Gerard Vilarem, Improving light fastness of natural dyes on cotton yarn. Dyes and Pigments, 70, 3, 238-245 (2006).

6. Habip Dayioglu, Dilek Kut, Nigar Merdan and Seyda Canbolat, The effect of dyeing properties of fixing agent and plasma treatment on silk fabric dyed with natural dye extract obtained from Sambucus ebulus L. plant. Procedia - Social and Behavioral Sciences, 195 (3), 1609-1617 July (2015).

7. Padma, S., Vankar, Rakhi Shanker and Avani Verma, Enzymatic natural dyeing of cotton and silk fabrics without metal mordants. Journal of Cleaner Production, 15 (15), 1441-1450 (2007).

8. Calderin, Jay, Form, Fit, Fashion and Rockport. pp. 125-26. ISBN 978-1-59253541-5(2009).

9. Yie-Chan Chiu, I., Chen Chou, Wei-Chuan Tseng and Chen-Chi M. Ma, Egypt. J. Chem. 58, No. 4 (2015) 
Preparation and thermal properties of diglycidylether sulfone epoxy. Polymer Degradation and Stability, 93 (3), 668-676(2008).

10. Crini, G., Non-conventional low-cost adsorbents for dye removal: A review. Bioresour Technol, 60, 67-75 (2006).

11. Won Keun Son, Ji Ho Younk and Won Ho Park, Antimicrobial cellulose acetate nanofibers containing silver nanoparticles. Carbohydrate Polymers (4) 65, 430-434 (2006).

12. Bahtiyari, M.I., Laser modification of polyamide fabrics. Optics \& Laser Technology, 43 (1), 114-118 (2011).

13. Monica Periolatto and Franco Ferrero, Cotton and polyester surface modification by methacrylic silane and fluorinated alkoxysilane via sol-gel and UV-curingcoupled process. Surface and Coatings Technology, 271, 165-173 (2015).

14. Mahbubul Basharm, M., Abu Bakar Siddiquee, Md. and Mubarak, A. Khan, Preparation of cotton knitted fabric by gamma radiation: A new approach. Carbohydrate Polymers, 120, 92-101 (2015).

15. Woo, R.S.C., Chen, Y., Zhu, H., Li, J., Kim, J. K. and Leung, C.K.Y. Environmental degradation of epoxy-organoclay nanocomposites due to UV exposure. Part I: Photodegradation. Composites Science and Technology, 67, 3448-3456 (2015).

16. Wu, F.C., Tseng, R.L. and Juang, R.S., Kinetic modeling of liquidphase adsorption of reactive dyes and metal ions on chitosan. Water Res. 35, 613-318 (2001).

17. Qian Zhao, Xiaoyu Gu, Sheng Zhang, Mingzhe Dong, Peng Jiang and Zhongwu Hu, Surface modification of polyamide 66 fabric by microwave induced grafting with 2-hydroxyethyl methacrylate. Surface and Coatings Technology, 240 (15), 197203 (2014).

18. Bes-Pía, A., Iborra-Clar, A., Mendoza-Roca, J.A., Iborra-Clar, M.I. and Alcaina-Miranda, M.I., Nanofiltration of biologically treated textile effluents using ozone as a pre-treatment. Desalination, 167, 387-392(2004).

19. Phipps and Elena, Cochineal Red The Art History of a Color, p.34. Yale University Press, New Haven and London. ISBN 978-0-300-15513-6 (2010) .

20. Hebeish, A., Elnagar, Kh., Helal, M.H., Ragab, M.S. and Shaaban, M.F., UV/O preirradiated cotton fabric-containing chitosan for effective removal of heavy metals. Materials Sciences and Applications, 5, 698-707(2014).

21. Shoji Aoki, Kunio Fujiwara, Takanobu Sugo and Koichi Suzuki , Antimicrobial fabric adsorbed iodine produced by radiation-induced graft polymerization. Radiation Physics and Chemistry, 84, 242-245 ( 2013).

22. Osman, Eman, M. Michael Monira, N. and Gohar, Hoda, The effect of both UV/ozon and chitosan on natural farics. International Journal of Chemistry, 2 (2), 28 39 (2010).

Egypt. J. Chem. 58, No. 4 (2015) 
23. Hebeish, A., Shaaban, M.F. and Ahmed, K.A., Chitosan induced bactericidal properties and improved printability to cotton fabrics. J. Appl. Sci. Res. 9(3), 17541758 (2013).

24. Alfred, A. Christy, Olav, M. Kvalheim and Rance, A. Velapoldi, Quantitative analysis in diffuse reflectance spectrometry: A modified Kubelka-Munk equation. Infrared and Raman Spectroscopy, 9 (1), 19-27(1995).

25. Sahdeo Prasad, Subash, C. Gupta, Amit, K. Tyagi and Bharat, B. Aggarwal, Curcumin, a component of golden spice: From bedside to bench and back. Biotechnology Advances, 32 (6), 1053-1064 (2014).

26. Dania Akbik, Maliheh Ghadiri, Wojciech Chrzanowski, and Ramin Rohanizadeh, Curcumin as a wound healing agent. Life Sciences , 116 (1), 1-7(2014).

27. Shaaban, M. F., El-Alfy, E. A. and Zemzem, N. E., Utilization of amminated GMAg-jute copolymers for the removal of $\mathrm{Hg} 2+$ and $\mathrm{Zn}^{2+}$ ions from their aqueous solutions, $7^{\text {th }}$ Inter. Conference of TRD-NRC-Cairo-Egypt, 7(12),429-432 (2010). 


\section{إتجاه مبتكر لإحداث طريقة صباغة الموردتن للأقمشة القطنية}

على على حبيش ، خالا ابراهيم مصطفى النجار”ومحمد فكرى شعبان

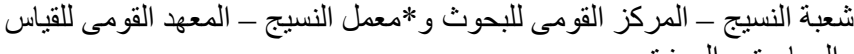

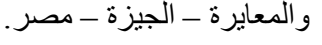

تهدف الدراسة الي إبتكار طرق جديدة لتحسين الخواص الثباتية لأقمشة القطن

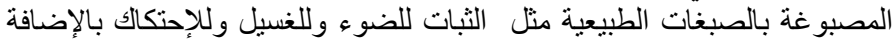

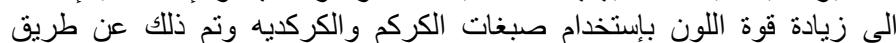

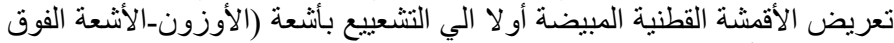

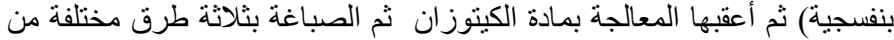

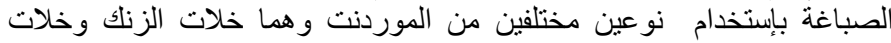

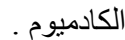

الطريقة الأولي: المعالجة بالموردنت قبل عملية الصباغة.

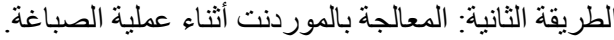

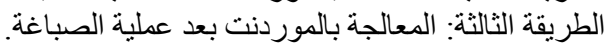

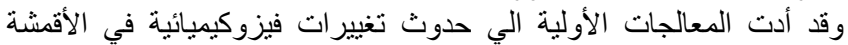

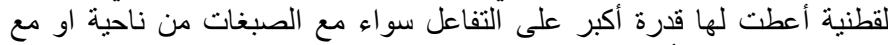

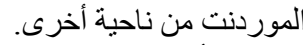

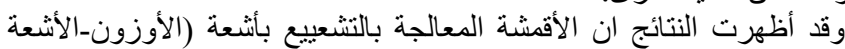

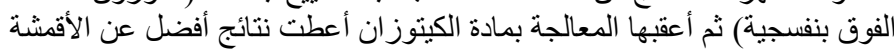

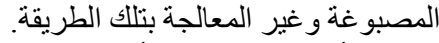
كما أظهرت النتائج ان أفضل النتائج نم الحصولة الطصول عليها على الترتيب هي : الطريقة الأولى من الصباغة الطب الطنان الطريقة الثانية > الطريقة الثالثة 